\title{
Results of hyperbaric oxygenation in chronic wound healing - preliminary findings
}

\author{
Wyniki terapii tlenem hiperbarycznym w leczeniu ran przewlekłych - \\ raport wstępny
}

\author{
Piotr Dzięgielewski ${ }^{1}$ Emilia Mikołajewska ${ }^{1,2,3}$, Aleksander Goch ${ }^{1,4}$ \\ ${ }^{1}$ Chair of Physiotherapy, Ludwik Rydygier Collegium Medicum in Bydgoszcz, Nicolaus Copernicus University in Torun, Poland \\ Head of the Chair: Prof. Aleksander Goch PhD \\ ${ }^{2}$ Rehabilitation Clinic, $10^{\text {th }}$ Military Clinical Hospital with Polyclinic, Bydgoszcz, Poland \\ Head of the Clinic: Krzysztof Radziszewski MD \\ ${ }^{3}$ Neurocognitive Laboratory, Interdiscipinary Centre for Modern Technologies, Nicolaus Copernicus University in Torun, Poland \\ Head of the Laboratory: Prof. Włodzisław Duch PhD \\ ${ }^{4}$ Cardiology and Cardiosurgery Clinic, Military Clinical Hospital No. 10 with Policlinic in Bydgoszcz, Poland \\ Head of the Clinic: Prof. Aleksander Goch MD, PhD
}

Key words: chronic wounds, hyperbaric oxygenation, wounds healing, wounds care.

Słowa kluczowe: rany przewlekłe, tlenoterapia hiperbaryczna, leczenie ran, opieka nad ranami.

\begin{abstract}
Introduction: Improved wound healing decreases the risk of complications, increases the possibilities of further treatment, rehabilitation, and care, and improves the quality of life for the patients.

Aim of the research: The aim of this paper is to present the outcomes of a study of chronic wound healing using hyperbaric oxygenation therapy (HBOT). The indirect aim of the study was also to assess correlations, i.e. statistical relationships, between observed changes of pain assessment, wound length, wound width, and transcutaneous oximetry and establish prognostic signs.

Material and methods: Inclusion criteria meet the medical records of thirty adult patients with chronic wounds treated with HBOT. Wound length, wound width, and transcutaneous oximetry were measured before and after treatment. The pain was evaluated using the numerical rating scale before and after treatment.

Results: The response to HBOT varied from good to excellent. Favourable and statistically significant changes were observed in all measured areas: pain assessment, wound length, wound width, and transcutaneous oximetry.

Conclusions: The HBOT in adult patients with chronic wounds is an effective method of treatment. Age above 60 years, sex (male), and lack of obesity, if confirmed by further studies, can be useful prognostic signs. However, there is still little evidence. There is a strong need for more research.
\end{abstract}

\section{Streszczenie}

Wprowadzenie: Efektywniejsze leczenie ran zmniejsza ryzyko komplikacji, zwiększa możliwości dalszego leczenia, rehabilitacji i opieki oraz poprawia jakość życia pacjentów.

Cel badania: Przedstawienie wyników leczenia ran przewlekłych z wykorzystaniem hiperbarycznej terapii tlenowej. Pośrednim celem badania były również ocena zależności pomiędzy zaobserwowanymi zmianami w zakresie oceny bólu, długości rany, szerokości rany i oksymetrii przezskórnej oraz ustalenie czynników predykcyjnych.

Materiał i metody: Kryteria włączenia spełniły kartoteki medyczne 30 dorosłych pacjentów z ranami przewlekłymi leczonymi za pomoca tlenoterapii hiperbarycznej. Długość rany, szerokość rany oraz oksymetria przezskórna były mierzone przed terapią i po terapii. Ból oceniano za pomocą numerycznej skali oceny bólu przed leczeniem i po leczeniu.

Wyniki: Odpowiedź na terapię tlenem hiperbarycznym zmieniała się od dobrej do bardzo dobrej. Pozytywne i statystycznie istotne zmiany zaobserwowano we wszystkich mierzonych obszarach: oceny bólu, długości rany, szerokości rany i oksymetrii przezskórnej.

Wnioski: Terapia tlenem hiperbarycznym u dorosłych pacjentów z ranami przewlekłymi jest efektywną metodą terapeutyczną. Wiek powyżej 60 lat, płeć męska i brak otyłości mogą być użytecznymi czynnikami prognostycznymi, jeśli zostaną potwierdzone w kolejnych badaniach. Pomimo powyższych wyników ciągle konieczne są dalsze badania, gdyż obecne dowody są niewystarczające. 


\section{Introduction}

Improved wound healing decreases the risk of complications, increases the possibilities of further treatment, rehabilitation, and care, and improves the quality of life for the patients. Traditional wound therapy and care remains the mainstay management. Scientists still look for novel approaches towards wound healing, but none of them is predominant. Despite the application of diverse techniques, there is little evidence supporting their efficiency. An individualised approach to wound healing technologies is regarded as a key element of several novel approaches, including hyperbaric oxygenation therapy (HBOT) [1]. Hyperbaric oxygenation therapy is perceived as a novel basic or supplementary method in wound healing. Hyperbaric oxygenation therapy delivers 100\% oxygen above one atmospheric pressure (ATA) into the core of the wound [2]. According to Undersea and Hyperbaric Medical Society (UHMS) guidelines, HBOT pressurisation should be $\geq 1.4$ atm absolute pressure [3]. In this way HBOT delivers an increased amount of

Table 1. Clinical summary of the patients

\begin{tabular}{|c|c|}
\hline Parameter & $\begin{array}{c}\text { Patients } \\
N=30(100 \%)\end{array}$ \\
\hline \multicolumn{2}{|l|}{ Age [years]: } \\
\hline Min. & 26 \\
\hline Max. & 85 \\
\hline Mean & 57.87 \\
\hline SD & 14.16 \\
\hline Median & 60 \\
\hline \multicolumn{2}{|l|}{ Gender: } \\
\hline Female & $15(50 \%)$ \\
\hline Male & $15(50 \%)$ \\
\hline \multicolumn{2}{|l|}{ Value of body mass index (BMI): } \\
\hline Min. & 21.13 \\
\hline Max. & 55.1 \\
\hline Mean & 30.93 \\
\hline SD & 7.43 \\
\hline Median & 29.8 \\
\hline $\begin{array}{l}\text { Number of obese patients } \\
\left(\mathrm{BMI} \geq 30 \mathrm{~kg} / \mathrm{m}^{2}\right)\end{array}$ & $14(46.67 \%)$ \\
\hline \multicolumn{2}{|l|}{ Number of HBOT sessions: } \\
\hline Min. & 12 \\
\hline Max. & 30 \\
\hline Mean & 26 \\
\hline$\underline{\mathrm{SD}}$ & 6.04 \\
\hline Median & 29.05 \\
\hline
\end{tabular}

Min. - minimum, max. - maximum, SD - standard deviation. oxygen to the local tissues (wound). The pathophysiology underlying improved wound healing of HBOT is still under research - a comprehensive explanation of the recent concepts in aforementioned area has recently been published in papers by Kuffler [1] and by Asai et al. [4]. Hyperbaric oxygenation therapy increases cellular $\mathrm{pO}_{2}$ leading to more intense production of reactive oxygen species (ROS) and reactive nitrogen species (RNS). Thus HBOT can cause improvement in tissue perfusion and oxygenation, and also create sustained conditions for the wound healing process [5]. Hyperbaric oxygenation therapy can constitute a key element in maintaining optimal oxygenation, macroand microcirculation, and nutrition [6].

The clinical effectivity of HBOT seems to be beyond doubt. Its application significantly increases the percentage of completely healed patients (by up to 74-100\%) and minimises the number of amputations relative to traditional approaches [1].

\section{Aim of the research}

The aim of this paper is to present the outcomes of a study of chronic wound healing using HBOT. The hypothesis is that HBOT is effective in wound healing in adult patients.

\section{Material and methods}

The research design was a retrospective study. We reviewed the medical records of 89 adult patients with chronic wounds treated with HBOT. Thus the sample may be regarded as a convenience sample reflecting the real distribution of patients.

Patients were eligible for participation if they were 18 years of age or older and had suffered from chronic wounds, as confirmed by medical records. Absolute contraindications to HBOT (chemotherapy with certain agents, untreated pneumothorax, and history of spontaneous pneumothorax) and relative contraindications to HBOT (fever, systemic viral infections seizure disorder, retinal surgery, middle ear surgery, cataract exacerbation, spherocytosis, and optic neuritis) were carefully taken into consideration. No complications of HBOT (confinement anxiety, ear pain, a hypo- and hyperglycaemic event, shortness of breath, etc.) were recorded in reviewed medical records.

Thirty adult patients with chronic wounds met the aforementioned inclusion criteria. Their clinical summary is presented in Table 1.

Patients with chronic wounds were treated using HBOT. The intervention was provided in 2014 in a 12-person HBOT chamber Hipertech Zyron 12 (GTC, Sweden) in the Centre of Hyperbaric Oxygenation and Wound Healing of the Military Clinical Hospital No. 10 with Polyclinic in Bygoszcz, Poland. The participants received various numbers of HBOT sessions. 
Table 2. Statistical analysis of the study results for the whole group of patients

\begin{tabular}{|lcccccc|}
\hline $\begin{array}{l}\text { Variable } \\
\text { Before therapy: }\end{array}$ & $\boldsymbol{N}$ & Mean & Median & Min. & Max. & SD \\
\hline Numerical rating scale for pain assessment & 30 & 3.03 & 1 & 1 & 10 & 1.79 \\
\hline Max. wound length & 30 & 4.48 & 1.55 & 1 & 25 & 2.43 \\
\hline Max. wound width & 30 & 2.25 & 1.05 & 0.1 & 13.5 & 1.7 \\
\hline $\begin{array}{l}\text { Transcutaneous oximetry } \\
\text { After therapy: }\end{array}$ & 30 & 32.4 & 30 & 5 & 66 & 11.68 \\
\hline Numerical rating scale for pain assessment & 30 & 1.7 & 0 & 0 & 10 & 1.33 \\
\hline Max. wound length & 30 & 2.62 & 0.25 & 0 & 15 & 2.03 \\
\hline Max. wound width & 30 & 1.91 & 2 & 0 & 19 & 1.63 \\
\hline Transcutaneous oximetry & 30 & 37.3 & 38 & 12 & 58 & 9.65 \\
\hline
\end{tabular}

SD - standard deviation, max. - maximum, min. - minimum.

Wound length, wound width, and transcutaneous oximetry were measured before and after treatment. The pain was evaluated using a numerical rating scale before and after treatment.

The study was conducted in accordance with the Helsinki Declaration and the rules of Good Clinical Practice. Written, informed consent was obtained from each patient before the study.

\section{Statistical analysis}

All the data were analysed using the software Statistica version 12 . The results were calculated as mean, median, minimum value (min.), maximum value (max.), and standard deviation (SD). The Shapiro-Wilk test was used as a test for the normality of data. T-Student test and Wilcoxon's test were used to compare scores. The level of significance was set at $p \leq 0.05$.

The aim of the study was also to assess correlations, i.e. statistical relationships, between observed changes of pain assessment, wound length, wound width, and transcutaneous oximetry. Changes between results before therapy and results after therapy were determined as a result of the subtraction. To assess correlations Spearman's rank correlation coefficient (Spearman's rho) was used. Values of the correlation were perceived as: lack of correlation: $<0.2$, poor: $0.2-0.4$, moderate: $0.4-0.6$, severe: $0.6-0.8$, high: $0.8-$ 0.9 , and very high: $>0.9$.

\section{Results}

This research focused on looking for statistically significant and important changes reflecting recovery in a numerical rating scale for pain assessment, maximal wound length, maximal wound width, and transcutaneous oximetry. Values of the aforementioned parameters are often impaired in patients with chronic wounds, they allow other scientists to replicate the study, and are easy for clinical use. The results are shown in Table 2.

All changes in Table 2 were statistically significant: numerical rating scale for pain assessment $(p<0.001)$, max. wound length $(p<0.001)$, max. wound width $(p=0.002)$, and transcutaneous oximetry $(p<0.001)$.

Improvement of pain assessment occurred in $100 \%$ of patients, improvement of max. wound length occurred in $100 \%$ of patients, improvement of max. wound width occurred in $83.33 \%$ of patients, and improvement of transcutaneous oximetry occurred in $90 \%$ of patients.

The best results of the HBOT administration were achieved in particular groups of patients: men, over 60 years of age (median of age), with body mass index $(\mathrm{BMI})<30 \mathrm{~kg} / \mathrm{m}^{2}$ (i.e. non-obese patients).

The aforementioned values may serve as a ground for a prognosis (prognostic signs) for further studies and, if confirmed, clinical prognosis.

The main statistically relevant correlations observed in the study were as follows:

- in the whole group of patients (Table 3): moderate (positive) correlation between changes in wound width and wound length, between changes in wound length and transcutaneous oximetry, and poor (positive) correlation between changes in pain assessment and wound length, between changes in pain assessment and wound width, and between changes in pain assessment and transcutaneous oximetry,

- in the group of women: moderate (positive) correlation between changes in pain assessment and wound length, and poor (positive) correlation between changes in pain assessment and wound length, between changes in pain assessment and wound width, and between changes in pain assessment and transcutaneous oximetry,

- in the group of men: severe (positive) correlation between between changes in max. wound length and pain assessment, and moderate (positive) cor- 
Table 3. Correlations of the study results for the whole group of patients

\begin{tabular}{|c|c|c|c|c|}
\hline & $\begin{array}{l}\text { Change of numerical } \\
\text { rating scale for pain } \\
\text { assessment }\end{array}$ & $\begin{array}{l}\text { Change of max. } \\
\text { wound length }\end{array}$ & $\begin{array}{l}\text { Change of max. } \\
\text { wound width }\end{array}$ & $\begin{array}{c}\text { Change } \\
\text { of transcutaneous } \\
\text { oximetry }\end{array}$ \\
\hline $\begin{array}{l}\text { Change of numerical } \\
\text { rating scale for pain } \\
\text { assessment }\end{array}$ & - & 0.22 & 0.28 & 0.32 \\
\hline $\begin{array}{l}\text { Change of max. } \\
\text { wound length }\end{array}$ & & - & 0.521 & 0.491 \\
\hline $\begin{array}{l}\text { Change of max. } \\
\text { wound width }\end{array}$ & & & - & NS \\
\hline $\begin{array}{l}\text { Change of } \\
\text { transcutaneous } \\
\text { oximetry }\end{array}$ & & & & - \\
\hline
\end{tabular}

NS - non significant.

relation between changes in wound length and wound width,

- in the group of patients $\leq 60$ years old: moderate (positive) correlation between changes in pain assessment and wound length, between changes in wound length and transcutaneous oximetry, and poor (positive) correlation between changes in pain assessment and wound length, and between changes in pain assessment and transcutaneous oximetry,

- in the group of patients $>60$ years old: moderate (positive) correlation between changes in pain assessment and wound length, and between changes in wound length and wound width,

- in the group of patients with BMI $\leq 30 \mathrm{~kg} / \mathrm{m}^{2}$ : moderate (positive) correlation between changes in transcutaneous oximetry and wound length, and between changes in wound width and wound length, and poor (positive) correlation between changes in pain assessment and wound length,

- in the group of patients with BMI $>30 \mathrm{~kg} / \mathrm{m}^{2}$ : $\bmod$ erate (positive) correlation between changes in pain assessment and wound length, and between changes in pain assessment and wound width.

\section{Discussion}

The aforementioned results of the study show that HBOT can be considered as an effective treatment for patients with chronic wounds. The changes observed in patients as a result of the therapy were favourable. Analysis of correlations indicates important predictive relationships, which can be exploited later during further studies and in clinical practice.

The low number of relevant studies concerning application of HBOT in wound healing makes compartmental studies difficult. There is a need to admit that HBOT may be used as both a basic and a supplementary therapeutic method. A retrospective study by David et al. on HBOT outcomes in patients with osteoradionecrosis (ORN) showed that improvement occurred in $94.7 \%$ of patients [7], so there results are similar to ours. Kalani et al. proved HBOT to be more effective compared with traditional treatment in patients with diabetic foot ulcers (respectively, $76 \%$ vs. $48 \%$ of completely healed patients) [8]. Despite very high short-term improvement resulting from HBOT intervention in patients with neuropathic ulcers, the aforementioned improvement may disappear at the 2 -week follow-up [9]. Similar positive results in HBOTbased therapy of non-healing ulcers were reported by Kaur et al. [10]. According to current knowledge, the efficiency of HBOT may depend on many factors (e.g. the aetiology of the wound). Research by Ueno et al. showed HBOT to be less effective in wounds caused by diabetes mellitus and in patients who have undergone haemodialysis [11]. Contrary research by Boykin and Baylis showed short- and long-term effectivity of HBOT independently of wound aetiology [12]. Some of the factors influencing HBOT efficiency have not been identified so far - this fact increases the value of the prognostic signs identified by us. Similar results were shown in reports by Cochrane [5, 13-15].

We did not record any HBOT-related complications, but further research is needed concerning the safety of HBOT applications in patients in various clinical conditions. A study by Kaur et al. reported ear pain (17\%) and generalised seizures (0.5\%), and as adverse results of HBOT: ear discomfort/pain (20\%) and claustrophobia (13\%) [10].

Despite the fact that the results of our research can be perceived as significant and important, the main limitation of the current study is the relatively low number of participants and the lack of a reference group. But our design (and relatively low number of participants) is not rare in research on HBOT. Another limitation of our study may be the perceived selection of measurement tools. It supports replication of the study and usefulness of our results in clinical practice. The aforementioned tools should be at least easy to perform, time-efficient, accurate, and inexpensive. 
We intend to verify hypotheses concerning the efficiency of HBOT for wound healing in further research. We hope to continue this study on a larger sample of patients based on a randomised controlled trail (RCT) design. Directions for further research cover short- and long-term results of the use of HBOT alone and in combination with traditional therapies or further interventions. Many prognostic signs should be taken into consideration, including wound cause, age, sex, obesity, number of HBOT sessions, etc. Thus, the current research may be regarded as preliminary. More independent sources of knowledge are necessary to confirm the correlations between results of the HBOT and to gather more general dependencies. Based on the presented correlations, the assumption that it is hard to achieve simultaneous recovery in all measured areas may be true, but it requires deeper research. If confirmed, the regenerative potential of HBOT could improve the efficiency and decrease the costs of the therapy within the population of chronic wound patients [16-18].

\section{Conclusions}

Our findings confirm that HBOT is an effective therapy for adult patients with chronic wounds. There have been observed favourable and statistically significant changes in all measured areas: pain assessment, wound length, wound width, and transcutaneous oximetry. Age older than 60 years, sex (male), and lack of obesity (BMI $<30 \mathrm{~kg} / \mathrm{m}^{2}$ ) can be useful prognostic signs. However, there is still little evidence and a strong need for more research.

\section{Acknowledgments}

We would like to thank the following medical specialists for their assistance with the collection of our data: Kinga Grobelska MD, Hanna Śliwińska MD, Mariola Wnęk BSc.

\section{Conflict of interest}

The authors declare no conflict of interest.

\section{References}

1. Kuffler DP. Improving the ability to eliminate wounds and pressure ulcers. Wound Repair Regen 2015; 23: 312-7.

2. Feldmeier JJ, Matos LA. Kensington, Maryland: Undersea and Hyperbaric Medical Society; 2003. Hyperbaric Oxygen 2003. Indications and Results: The Hyperbaric Oxygen Therapy Committee Report.

3. Undersea \& Hyperbaric Medical Society. Indications for Hyperbaric Oxygen Therapy. 2014.

4. Asai J, Takenaka H, Ii M, Asahi M, Kishimoto S, Katoh N Losordo DW. Topical application of ex vivo expanded endothelial progenitor cells promotes vascularisation and wound healing in diabetic mice. Int Wound J 2013; 10: 527-33.
5. Eskes AM, Ubbink DT, Lubbers MJ, Lucas C, Vermeulen H. Hyperbaric oxygen therapy: Solution for difficult to heal acute wounds. Systematic review? World J Surg 2011; 35: $535-42$.

6. Klein KC, Guha SC. Cutaneous wound healing: current concepts and advances in wound care. Indian J Plast Surg 2014; 47: 303-17.

7. David LA, Sàndor GK, Evans AW, Brown DH. Hyperbaric oxygen therapy and mandibular osteoradionecrosis: a retrospective study and analysis of treatment outcomes. J Can Dent Assoc 2001; 67: 384.

8. Kalani M, Jörneskog G, Naderi N, Lind F, Brismar K. Hyperbaric oxygen $(\mathrm{HBO})$ therapy in treatment of diabetic foot ulcers. Long-term follow-up. J Diabetes Complications 2002; 16: 153-8.

9. Kessler L, Bilbault P, Ortéga F, Grasso C, Passemard R, Stephan D, Pinget M, Schneider F. Hyperbaric oxygenation accelerates the healing rate of nonischemic chronic diabetic foot ulcers: a prospective randomized study. Diabetes Care 2003; 26: 2378-82.

10. Kaur S, Pawar R, Banerjee R, Garg R. Evaluation of the efficacy of hyperbaric oxygen therapy in the management of chronic nonhealing ulcer and role of periwound transcutaneous oximetry as a predictor of wound healing response: a randomized prospective controlled trial. J Anaesthesiol Clin Pharmacol 2012; 28: 70-5.

11.Ueno T, Omi T, Uchida E, Yokota H, Kawana S. Evaluation of hyperbaric oxygen therapy for chronic wounds. J Nippon Med Sch 2014; 81: 4-11.

12. Boykin JV, Baylis C. Hyperbaric oxygen therapy mediates increased nitric oxide production associated with wound healing: a preliminary study. Adv Skin Wound Care 2007; 20: $382-8$

13. Eskes A, Ubbink DT, Lubbers M, Lucas C, Vermeulen H. Hyperbaric oxygen therapy for treating acute surgical and traumatic wounds. Cochrane Database Syst Rev 2010; 10: CD008059.

14. Eskes A, Vermeulen H, Lucas C, Ubbink DT. Hyperbaric oxygen therapy for treating acute surgical and traumatic wounds. Cochrane Database Syst Rev 2013; 12: CD008059.

15. Kranke P, Bennett MH, Martyn-St James M, Schnabel A, Debus SE. Hyperbaric oxygen therapy for chronic wounds. Cochrane Database Syst Rev 2012; 4: CD004123.

16. Perdrizet GA. Principles and practice of hyperbaric medicine: a medical practitioner's primer, part II. Conn Med 2014; 78: 389-402.

17. Goldstein LJ. Hyperbaric oxygen for chronic wounds. Dermatol Ther 2013; 26: 207-14.

18. Mills BJ. Wound healing: the evidence for hyperbaric oxygen therapy. Br J Nurs 2012; 21: 28, 30,32, 34.

\section{Address for correspondence:}

\section{Emilia Mikołajewska}

Chair of Physiotherapy

Ludwik Rydygier Collegium Medicum in Bydgoszcz

Nicolaus Copernicus University in Torun

ul. M. Skłodowskiej-Curie 9, 85-094 Bydgoszcz, Poland

Phone: +48 607889909

E-mail: e.mikolajewska@wp.pl 